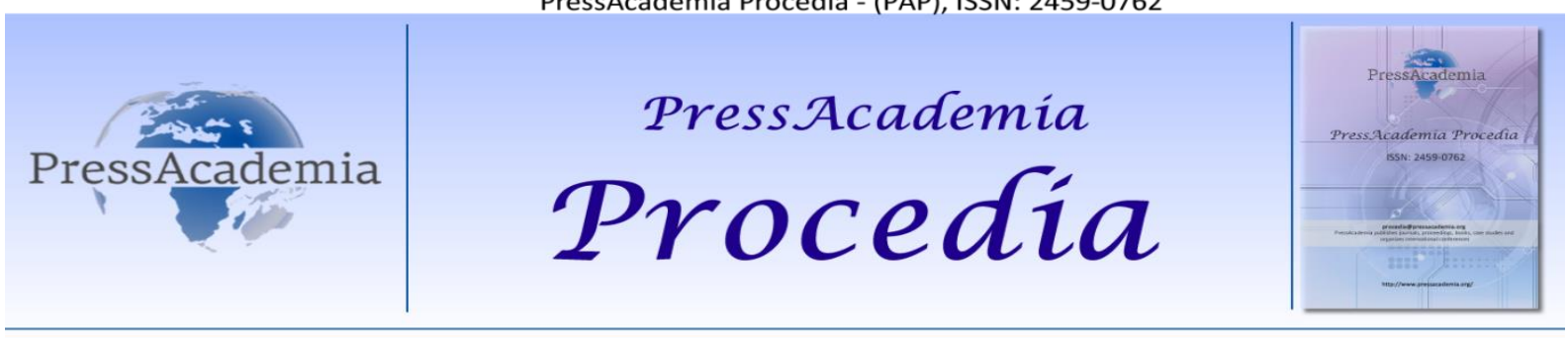

Global Business Research Congress (GBRC), May 24-25, 2017, Istanbul, Turkey.

\title{
DETERMINATION OF THE LEVEL OF ORGANIZATIONAL SINIZM ON ACADEMIC STAFF
}

\section{DOI: 10.17261/Pressacademia.2017.662}

PAP- GBRC-V.3-2017(88)-p.808-814

Erdoğan Kaygın ${ }^{1}$, Onur Kavak ${ }^{2}$

${ }^{1}$ Kafkas Üniversitesi IïBF. Kars, Merkez. erdogankaygin@hotmail.com

${ }^{2}$ Kafkas Üniversitesi SMYO. Kars, Sarıkamış. onurkavak 046@hotmail.com

\section{To cite this document}

Kaygın, E and O. Kavak, (2017). Determination of the level of organizational sinizm on academic staff. PressAcademia Procedia (PAP), V.3, p.808-814.

Permemant link to this document: http://doi.org/10.17261/Pressacademia.2017.662

Copyright: Published by PressAcademia and limited licenced re-use rights only.

\begin{abstract}
The aim of this study was to determine the level of organizational sinizm which means working staff grow away from loyalty and have negative thoughts. For that, a research was conducted on the academic staff of Kafkas University. A moderate level of general sinizm was observed based on the results. The organizational sinizm level was also determined to be moderate as well. It has been observed that particalarly, the stayment of ' the similarity between the things said to be done and things done in reality was low' had the highest mean.
\end{abstract}

Keywords: Sinizm, organizational sinizm, academic staff

JEL Codes: M10, M16, M19

\section{ÖRGÜTSEL SINIZM DÜZEYININ BELIRLENMESi: KAFKAS ÜNIVERSITESI ÖRNEĞi}

\section{ÖZET}

Bu çalışmanın amacı, çalışanların örgütsel bağlılıktan uzaklaşarak işletmeleri ile ilgili olumsuz düşüncelere sahip olmasını ifade eden örgütsel sinizm düzeyini tespit etmektir. Bu amaçla Kafkas Üniversitesi akademik personeli üzerinde bir araştırma yapılmıştır. Ortaya çıkan bulgularda genel sinizm düzeyinin orta seviyede olduğu görülmüştür. Ayrıca örgütsel sinizm düzeyinin de orta seviyede olduğu belirlenmiştir. Özellikle "yapılacağı söylenenler ile gerçekte yapılanlar arasındaki benzerliğin az olduğu" ifadesinin en yüksek ortalamaya sahip ifade olduğu görülmüştür.

Anahtar kelimeler: Sinizm, Örgütsel Sinizm, Akademik Personel.

JEL Codes: M10, M16, M19

\section{GiRiş}

Örgütler kendilerini oluşturan insanlar gibi canlı mekanizmalardır. Bu bağlamda örgütler kendisini oluşturan bireylerin düşünce ve ruh halinden olumlu ya da olumsuz olarak etkilenirler. Örgüt içerisinde bulunan çalışanların performanslarının yüksek olması, örgütsel verimliliğin yüksek olmasının önünü açan başlıca sebeplerdendir. Bunun aksine bazı sebeplerle örgüt mensuplarının, örgüt değerlerinden uzaklaşması ve örgüte karşı olumsuz tutumlar sergilemesi gibi durumlarla karşılaşılabilir (James, 2005). Çalışanların, örgütsel değerlerden uzaklaşması ve karşı tutum içine girmesi örgütsel performansa doğrudan etki edeceğinden örgütün devamlılığı ve başarısı açısından önem arz eden bir sorun olarak karşımıza çıkmaktadır. Bu sorun felsefi bir düşünce olarak M.Ö 500'lü yıllara kadar uzanan antik yunanda ortaya çıkmış siniklik kavramı ile açıklanmaktadır 
(Mantere ve Martinsuo 2001, Akt. Kalağan ve Güzeller 2010). "Sinik" teriminin kökeninin Yunanca "köpek" anlamına gelen "kunikos" tan türetildiği düşünülmektedir. Bu adlandırmanın temelinin köpeksi hal ve hareketleri ile bilinen Sinop'lu Diogenes'e kadar uzandığı ve Diogenes'in hayat tarzını ifade etmek için kullanılmış bir kavram olabileceği düşünülmektedir (Dean, Brandes, Dharwadkar, 1998). Sinizmin, hayal kırıklığı, umutsuzluk, engellenme, önemsenmeme gibi kaynaklardan beslendiğini öne süren ve bireyin; kişi, grup, toplumsal gelenek ve kurumlara karşı olumsuz tutum sergilemesi olarak tanımlayan Anderson'a göre siniklik bireyin yaşadığı olumsuzlukların bir sonucu olarak kendini gösteren bir davranış şeklidir (Anderson,1996). Çalkantılı çevre koşullarında en iyi olmanın bir zorunluluk olduğu günümüzde örgütsel sinizm gibi işletmeyi olumsuz etkileyen faktörlerin belirlenmesi ve önlenmesi örgütsel başarı için önemlidir. Bu öneminden dolayı çalışmada örgütsel sinizm konusu ele alınmış ve Kafkas Üniversitesi akademik personeli üzerinde araştırma yapılımıştır.

\section{LITERATÜR INCELEMESI}

\section{1. Örgütsel Sinizm}

Son yıllarda örgütsel davranış alanında yapılan çalışmalar iki önemli husus üzerinde yoğunlaşmaktadır. Bunlardan ilki örgütsel performansın artırılması için örgüte mensup çalışanların verimliliklerini artırıcı faktörlerin geliştirilmesi ve ikinci olarak örgüt çalışanlarının verimliliğine olumsuz etki eden unsurların azaltılması, mümkünse ortadan kaldırılması doğrultusunda yapılan çalışmalardır (Parker vd., 2013). Örgütsel davranış ile ilgili yapılan bu çalışmalar örgüt başarısının, örgüt çalışanlarının tutum, davranış ve algıları ile ilişkili olduğunu açıkça ortaya koymaktadır. Dean ve meslektaşları (1998), çok sayıda iş görenin mensubu oldukları örgüt hakkında olumsuz ve negatif tutumlar sergilemesi, örgütsel bağlılık, örgütsel değer gibi kavramlardan uzaklaşmaları dahası bu durumun gittikçe artan bir hal alması hususu üzerinde durarak bu durumu "örgütsel sinizm" olarak adlandırmıştır. Dean ve meslektaşları tarafından yapılan örgütsel sinizm tanımlaması, örgütsel sinizmin bir kavram haline dönüşmesine büyük katkı sağlamış ayrıca literatürde kendisine önemli bir yer edinmiştir. Bu tanımlamaya göre örgütsel sinizm örgüt çalışanlarının örgüte karşı sergiledikleri negatif tutumdur. Çalışanların sergiledikleri bu negatif tutum, üç başlık altında toplanmış ve şu şekilde ele alınmıştır (Dean vd., 1998): Örgütün dürüstlük kavramının uzağında ve samimiyetsiz olduğu düşüncesi, örgüt değerlerin varlığına ilişkin negatif tutum, eksik olduğuna inanılan kavramlar ile ilgili örgüte karşı yapılan eleştiri ve aşağılama hali.

Dean ve meslektaşlarının yapmış olduğu bu tanımlamadan hareketle ele alınan başlıklar incelendiğinde örgütsel sinizmin "bilişsel", "duyuşsal" ve "davranışsal" boyutlarının olduğu anlaşılmaktadır. Siniklerin karakteristik özelliklerinden olan diğer insanların güvensiz, çıkarcı, samimiyetsiz ve yalancı olduğu inancı, örgüte mensup bireyin, örgütün kendisine ihanet ettiği algısına kapılması ile örgütsel sinizme dönüşür. Bu durum örgütsel sinizmin bilişsel boyutuyla açıklanabilir (Özgener $v d$., 2008). Tanımın ikinci kısmında Dean ve meslektaşları, siniklerin nesne ve bireylere karşı alaycı, küçümseyici, saygısız, kızgın, utanç ve nefret gibi negatif tutumlar içinde olmasını sinizmin duyuşsal boyutuyla ilişkilendirerek ele almıştır (James, 2005). Son olarak Dean ve meslektaşları üçüncü kısmı davranışsal boyut ile açıklayarak iş görenin, örgütün samimiyet ve dürüstlük kavramlarına uzak olduğunu düşünerek yoğun eleştirileri, karamsar tutumları ile örgüte karşı alaycı, küçümser tavır içine girmeleri olarak değerlendirmektedir (Kutanis ve Çetinel, 2010).

\section{2. Örgütsel Sinizmin Neden ve Sonuçları}

Örgütsel Sinizmi; "Bir örgütün dürüstlükten yoksun olduğuna dair inançtır” şeklinde tanımlayan Abraham (2000), bu inancın, olumsuz duygusal tepkiler, prestij sarsıcı davranışlar ve örgüt devamlılığını tehdit eden sonuçları dolayısıyla, örgütsel çöküşün önünü açacak kadar etkin bir güç olduğunu ileri sürmektedir. Örgütün başarı ve devamlılığını bu denli etkileyen örgütsel sinizm örgüt içerisinde bir kere oluştuktan sonra, yönetim, çalışan, müşteri gibi örgütsel rolü bulunan tüm bireyleri etkisi altına alabilecek kadar etkin bir faktördür (Anderson, 1996). Örgütsel olarak sinik bir birey, örgüt içinde var olan sorunları tespit edilebilse dahi, insanlar ve insanlar tarafından oluşturulan örgütlerin doğası gereği eksiklik ve sorunlardan beslendiği inancıyla, var olan sorunların çözümünün mümkün olmayacağı ve bu anlamda sorunun çözümü için yapılan çabanın tümünün boşa olduğu inancı taşıyan kişidir (McClough vd., 1998). Böyle bir inanca sahip olan bir bireyin her geçen gün performansı düşecek ve işletmeye katkısı giderek azalacaktır.

Örgütsel sinizmin kendini gösterdiği örgütlerde birçok sorun ortaya çıkabilir. Örgüt içindeki sinik tutum, diğer örgüt mensuplarına da kısa sürede sirayet ederek, örgütün devamlılı̆ını tehdit edecek noktaya gelebilir, yönetim yetkisini elinde bulunduran kişi ya da makamlara karşı umutsuzluk, hayal kırıklığı, güvensizlik gibi sonuçlar ortaya çıkar. Bu düşüncelere sahip olan çalışanların düşük performans göstermelerine, yenilik ve gelişim faaliyetlerinin başarısızlık ile sonuçlanmasına neden olabilir (Byrne ve Hochwarter, 2007). 


\section{KAFKAS ÜNIVERSITESI AKADEMISYENLERININ GENEL SINIZM VE ÖRGÜTSEL SINIZM EĞiLIMLERININ TESPITi}

Çalışmanın amacı Kafkas Üniversitesi akademik personelinin genel sinizm ve örgütsel sinizm seviyelerinin tespit edilmesidir. Çalışmanın bir diğer amacı ise bazı demografik değişkenler açısından örgütsel sinizmi algılama farklılıklarının olup olmadığının belirlenmesidir.

\subsection{Veri ve Yöntem}

Araştırmamız Kafkas Üniversitesi akademik personelinin genel ve örgütsel sinizm düzeylerinin belirlenmesi amacı taşımaktadır. Bu sebeple araştırmamızın evreni, Kafkas Üniversitesi akademik personelinden oluşmaktadır (ilçe çalışanları hariç). Kafkas üniversitesinden çalışan akademik personel sayısı $768^{\prime}$ dir. Bu ana kütleden \%95'lik güvenilirlik sınırları içerisinde \%5'lik hata payı öngörülerek belirlenecek örneklem büyüklüğü 256 olarak hesaplanmıştır (http://www.surveysystem.com/sscalc.htm). Bununla birlikte daha yüksek bir anket düzeyine ulaşmak için 300 anket dağıtılmış, 210 anket geri dönmüş, geri dönen anketler içerisinden 38'inin gelişi güzel doldurulduğunu, 12'sinin normallik testi sonucunda normalliği bozduğu tespit edildiğinden, işleme alınmamıştır. Değerlendirmeye alınan anket sayısı 160'tır.

Çalışmamızda sinizm ve örgütsel sinizm seviyelerinin tespit edilebilmesi için kullanılabilecek yöntemler araştırılmış, yapılan araştırmalar sonucunda en uygun yöntemin anket yöntemi olduğuna karar verilmiştir. Kullanılan anket 3 farklı bölümden oluşmaktadır. Anketin birinci bölümünde demografik özelliklerin tespit edilmesi için hazırlanan 6 soru bulunmaktadır. İkinci bölümde Wrightman'in (1992) geliştirdiği 10 soruluk "Genel Sinizm" düzeyini ölçmeyi amaçlayan sorular bulunmaktadır. Üçüncü bölüm katılımcıların "Örgütsel Sinizm” düzeylerini ölçmek maksadıyla Brandes'in (1997) geliştirdiği 14 sorudan oluşan bölümdür.

\section{BULGULAR VE TARTIŞMA}

Genel sinizm ölçeği üzerinde faktör analizi yapılmış olup, yapılan analiz sonucunda K.M.O testi sonucu 0,712 çıkmıştır. Ortaya çıkan bu değer verilerin faktör analizi için uygun olduğunu göstermektedir. Korelasyon yeterliliğinin sağlandığı ise Bartlett's Sphericity testi sonucunun $(125,553)$ olmasıyla ortaya konulmaktadır. Faktörlerin toplam varyansı açıklama yeterliliği \%81,61 seviyesindedir.

Tablo 1: Genel Sinizm Faktör Analizi Sonuçları

\begin{tabular}{|c|c|c|c|c|c|}
\hline Faktörler & Yükü & Özdeğeri & A.Varyans & Ortalama & Alfa \\
\hline Davranışsal Boyut (4 madde) & & 3,389 & 33,888 & 2,9688 & ,876 \\
\hline $\begin{array}{l}\text { İnsanların çoğu içten içe başkalarına yardım etmek için elinden } \\
\text { geleni yapmaktan hoşlanmazlar }\end{array}$ &, 881 & & & & \\
\hline $\begin{array}{l}\text { İnsanların çoğu yakalanmayacağından emin olsa para ödemeden } \\
\text { dolmuşa biner }\end{array}$ &, 854 & & & & \\
\hline İnsanların çoğu fırsat bulursa vergi kaçırır & 822 & & & & \\
\hline Çoğu insan kendini beğenmiştir. & 755 & & & & \\
\hline Duyuşsal Boyut (3 madde) & & 2,920 & 29,202 & 2,4958 & 853 \\
\hline $\begin{array}{l}\text { Günümüz dünyasında pek çok insan cömert insanları istismar ettiği } \\
\text { için cömert insanları görmek acıdır. }\end{array}$ & 899 & & & & \\
\hline $\begin{array}{l}\text { Tipik bir öğrenci etik standartlara sahip olsa bile sınavda herkes } \\
\text { yaptığında kopya çeker. }\end{array}$ & ,789 & & & & \\
\hline $\begin{array}{l}\text { İnsanlar dürüstlük ve ahlaka ilişkin etik standartlara sahip olduklarını } \\
\text { ifade ederler ancak çok az insan bunlara uyar }\end{array}$ &, 758 & & & & \\
\hline Bilişsel Boyut (3 madde) & & 1,853 & 18,525 & 2,3438 &, 530 \\
\hline Çoğu insan arzu ettiği şeyler ile ilgili dürüst değildir & 883 & & & & \\
\hline $\begin{array}{l}\text { İnsanlar diğer insanlarla gerçekten ilgilenmez ancak ilgileniyor gibi } \\
\text { görünürler }\end{array}$ & 880 & & & & \\
\hline Bir çıkarı olduğunda insanların çoğu yalan söyler &, 744 & & & & \\
\hline \multicolumn{6}{|c|}{$\begin{array}{l}\text { Faktör çıkarma metodu: Temel bileşenler analizi; Döndürme metodu: Varimax } \\
\text { KMO Örneklem Yeterliliği: \%.71,2 .; Bartlett's Küresellik Testi için } X^{2}: 1,25553 ; \text { sd: 45; p=000, p<0.0001; } \\
\text { Açıklanan toplam varyans: \%81,615; Ölçeğin tamamı için güvenirlik katsayısı: }\end{array}$} \\
\hline
\end{tabular}

Yapılan analiz sonucunda ölçek sorularının üç faktör altında toplandığı görülmüştür. Genel sinizm ile ilgili literatürde böyle bir sınıflandırmaya benzer nitelikte "Dean ve meslektaşları." tarafından yapılan ve örgütsel sinizmi bilişsel duyuşsal ve 
davranışsal boyutlara ayıran çalışmaya rastlanmıştır. Buradan hareketle bu üç faktör bilişsel, duyuşsal ve davranışsal boyut olarak çalışmamızda yer bulmuştur. Genel sinizm düzeyini ölmek maksadıyla katılımcılara sunulan ölçeğin güvenilirlik analizi sonucunda Cronbach's Alpha değeri 0,84 olarak hesaplanmış olup, bu değer ilgili ölçeğin yüksek güvenilir olduğunu göstermektedir. Yapılan güvenilirlik analizi sonucu faktörlerin güvenilirliğinin (Cronbach's Alpha değeri sırasıyla 0,53, 0,85 ve 0,87) kabul edilebilir değerlerde olduğu görülmüştür (Özdamar, 2002:673).

\section{Örgütsel Sinizm Ölçeği Faktör Analizi Bulguları}

Örgütsel Sinizm ölçeği üzerinde faktör analizi yapılmış olup, yapılan analiz sonucunda K.M.O testi sonucu 0,793 çıkmıştır. Ortaya çıkan bu değer verilerin faktör analizi için uygun olduğunu göstermektedir. Korelasyon yeterliliğinin sağlandığı ise Bartlett's Sphericity testi sonucunun $(262,633)$ olmasıyla ortaya konulmaktadır. Faktörlerin toplam varyansı açıklama yeterliliği \%74,74 seviyesindedir.

Tablo 2: Örgütsel Sinizm Faktör Analizi Sonuçları

\begin{tabular}{|c|c|c|c|c|c|}
\hline Faktörler & Yükü & Özdeğeri & A.Varyans & Ortalama & Alfa \\
\hline Davranışsal Boyut (4 madde) & & 2,904 & 16,605 & 2,6422 & 604 \\
\hline $\begin{array}{l}\text { Diğer çalışanlara çalıştığım fakültede işlerin nasıl } \\
\text { yürütüldüğü hakkında konuşurum }\end{array}$ & 913 & & & & \\
\hline $\begin{array}{l}\text { Fakülte dışında arkadaşlarıma, çalıştığım fakültede olanlar } \\
\text { hakkında yakınırım }\end{array}$ & 896 & & & & \\
\hline $\begin{array}{l}\text { Çalıştığım fakültede herhangi bir şey olduğunda çalışma } \\
\text { arkadaşlarımla anlamlı bir bakışma olur }\end{array}$ & ,781 & & & & \\
\hline $\begin{array}{l}\text { Çalıştığım fakültenin uygulama ve politikalarını diğer } \\
\text { çalışanlar ile eleştiririm }\end{array}$ & 683 & & & & \\
\hline Duyuşsal Boyut (5 madde) & & 4,256 & 38,685 & 2,1400 & ,971 \\
\hline Çalıştığım fakülteyi düşündüğüm zaman sinirlenirim & ,948 & & & & \\
\hline $\begin{array}{l}\text { Çalıştığım fakülteyi düşündüğüm zaman kızgınlık } \\
\text { hissederim }\end{array}$ & ,948 & & & & \\
\hline Çalıştığın fakülteyi düşündüğüm zaman gerilirim & ,935 & & & & \\
\hline $\begin{array}{l}\text { Çalıştığım fakülteyi düşündüğüm zaman kaygılanırım ve } \\
\text { endişelenirim }\end{array}$ & 874 & & & & \\
\hline $\begin{array}{l}\text { Kendimi çalıştığım fakültenin uygulama ve sloganları ile } \\
\text { dalga geçerken bulurum }\end{array}$ & 829 & & & & \\
\hline Bilişsel Boyut (5 madde) & & 3,304 & 19,454 & 3,1196 &, 522 \\
\hline $\begin{array}{l}\text { Çalıştığım fakültenin çalışanlarından beklediği davranışlar } \\
\text { ve ödüllendirdiği davranışlar farklıdır }\end{array}$ & ,943 & & & & \\
\hline $\begin{array}{l}\text { Çalıştığım fakültede politikalar, amaçlar ve uygulamaların } \\
\text { çok az ortak noktası vardır }\end{array}$ & ,852 & & & & \\
\hline $\begin{array}{l}\text { Çalıştığım fakültenin yapacağını söylediği şeyler ile } \\
\text { gerçekten yapılanlar arasında çok az benzerlik olduğunu } \\
\text { görüyorum }\end{array}$ & 829 & & & & \\
\hline $\begin{array}{l}\text { Çalıştığım fakültede söylenen ile yapılanın farklı olduğuna } \\
\text { inanıyorum }\end{array}$ & ,721 & & & & \\
\hline $\begin{array}{l}\text { Çalıştığım fakültede bir şey yapılacağı söylendiği zaman } \\
\text { bunun gerçekten yapılıp yapılmayacağı konusunda şüphe } \\
\text { duyarım }\end{array}$ & 642 & & & & \\
\hline \multicolumn{6}{|c|}{$\begin{array}{l}\text { Faktör çıkarma metodu: Temel bileşenler analizi; Döndürme metodu: Varimax } \\
\text { KMO Örneklem Yeterliliği: \%.79,3.; Bartlett's Küresellik Testi için } X^{2}: 262,633 ; \text { sd: } 61 ; p=000, p<0.0001 ; \\
\text { Açıklanan toplam varyans: \%74,744; Ölçeğin tamamı için güvenirlik katsayısı: } \\
\text { Yanıt kategorileri: 1: Kesinlikle Katılmıyorum, 2: Katılmıyorum, 3: Kararsızım, 4: Katılıyorum, 5: Kesinlikle } \\
\text { Katılıyorum }\end{array}$} \\
\hline
\end{tabular}

Örgütsel sinizm düzeyini ölmek maksadıyla katılımcılara sunulan ölçeğin güvenilirlik analizi sonucunda Cronbach's Alpha değeri 0,88 olarak hesaplanmış olup, bu değer ilgili ölçeğin yüksek güvenilir olduğunu göstermektedir. Çalışmada örgütsel 
sinizmin alt boyutları olarak yer alan bilişsel boyut, duygusal boyut ve davranışsal boyutların yapılan güvenilirlik analizi sonucu faktörlerin güvenilirliğinin (Cronbach's Alpha değeri sırasıyla 0,52, 0,97 ve 0,60) kabul edilebilir değerlerde olduğu görülmüştür.

\section{A. Demografik Özelliklere ilişkin Bulgular}

Araştırmaya Kafkas Üniversitesi akademik personellerinden toplam 160 kişi katılmıştır. Tablo 1'den de anlaşılacağı üzere, anketimize katılan akademisyenlerin \%38,8'i (62) kadın, \%61,2'si (98) erkektir. Yine anketimize katılan akademisyenlerin \%69,4'ü evli iken \%30,6 sı ise bekârdır. Çalışmamıza katılan akademisyenlerin yaş dağııımları incelendiğinde, yaş aralıklarının sayısal oranı sırasıyla; 77 kişi ile $(\% 48,1)$ 30-39 yaş, 50 kişi ile $(\% 31,2)$ 20-29 yaş, 23 kişi ile $(\% 14,4)$ 40-49 yaş ve son olarak 10 kişi ile $(\% 6,2) 50$ ve üstü yaş şeklinde dağılım göstermektedir. Bu dağılımlar incelendiğinde çalışmamıza katılan akademisyenlerin yaş dağılımında sayısal üstünlüğü orta yaş ve orta yaş altı akademisyenlerin oluşturduğu görülmektedir.

Çalışmaya katılan akademisyenlerin unvanlarına göre dağılımları sırasıyla; \%30 ile (48) Öğretim Görevlisi, \%25 ile (40) Araştırma Görevlisi, \%22,5 ile (36) Yardımcı Doçent, \%11,9 ile (19) Okutman ve \%10,6 ile (17) doçent ve profesörlerden oluşmaktadır. Çalışmada yer alan akademisyenlerin mesleki kıdemleri incelendiğinde 1-5 yıl arası bu meslekte görev yapanların \%60,0 (96) sayısal oran ile çalışmamızın büyük bir kısmını oluşturduğu görülmektedir. Bunu sırasıyla \%25,6 ile (41) 6-10 yıl arası çalışanlar, \%9,4 ile (15) 11-15 yıl arası çalışanlar, \%3,1 ile ( 5) bir yıldan az çalışanlar ve son olarak \%1,9 oran ile (3) 15 yıl üstü çalışanlar takip etmektedir Katılımcıların Kafkas üniversitesi bünyesinde çalıştıkları mesleki kıdemleri incelendiğinde sayısal oranları sırasıyla; 1-5 yıl arası çalışanların \% 59,4 (95), bir yıldan az çalışanların \%16,2 (26), 6-10 yıl arası çalışanların \%15,0 (24), 11-15 yıl arası çalışanların \%9,4 (15), olduğu görülmektedir.

\section{B. KATILIMCILARIN GENEL SINIZM DÜZEYINE ILIŞKIN BULGULAR}

Araştırmaya katılanların genel sinizm düzeylerini belirlemek amacıyla ortalama ve standart sapma değerleri belirlenmiștir. ifadeler aşağıda belirtilen değerlere göre yorumlanmıştır.

1 - 1,79 çok düşük,

$1,80-2,59$ düşük,

$2,60-3,39$ orta,

$3,40-4,19$ yüksek,

$4,20-5.00$ çok yüksek.

Tablo 3: Genel Sinizm Eğilimine Yönelik Ortalama ve Standart Sapma Değerleri

\begin{tabular}{|l|l|l|l|}
\hline Ölçek maddeler & $\mathbf{N}$ & $\boldsymbol{X}$ & Ss \\
\hline İnsanların çoğu yakalanmayacağından emin olsa para ödemeden dolmuşa biner & 160 & 2,97 & 1,20 \\
\hline Çoğu insan kendini beğenmiştir & 160 & 3,41 & 1,11 \\
\hline Bir çıkarı olduğunda insanların çoğu yalan söyler & 160 & 3,89 & 0,90 \\
\hline İnsanlar diğer insanlarla gerçekten ilgilenmez ancak ilgileniyor gibi görünürler & 160 & 3,42 & 1,01 \\
\hline İnsanların çoğu fırsat bulursa vergi kaçırır & 160 & 3,04 & 1,14 \\
\hline $\begin{array}{l}\text { İnsanların çoğu içten içe başkalarına yardım etmek için elinden geleni yapmaktan } \\
\text { hoşlanmazlar }\end{array}$ & 160 & 2,69 & 0,77 \\
\hline Çoğu insan arzu ettiği şeyler ile ilgili dürüst değildir & 160 & 3,65 & 0,93 \\
\hline $\begin{array}{l}\text { İsanlar dürüstlük ve ahlaka ilişkin etik standartlara sahip olduklarını ifade ederler ancak } \\
\text { çok az insan bunlara uyar }\end{array}$ & 160 & 4,02 & 0,97 \\
\hline Tipik bir öğrenci etik standartlara sahip olsa bile sınavda herkes yaptığında kopya çeker & 160 & 3,42 & 1,29 \\
\hline $\begin{array}{l}\text { Günümüz dünyasında pek çok insan cömert insanları istismar ettiği için cömert insanları } \\
\text { görmek acıdır }\end{array}$ & 160 & 3,09 & 1,58 \\
\hline Tüm ölçek & & 3,36 & \\
\hline
\end{tabular}

Tablo 3 incelendiğinde, araştırmaya katılan akademisyenlerin genel sinizm eğilimi $(\bar{x}=3,36)$ çıkmıştır. Buna göre genel sinizm eğilimi orta düzeyde olduğu görülmektedir. Ifadeler bazında durum ele alındığında en yüksek ortalamaya sahip ifadenin "insanlar dürüstlük ve ahlaka ilişkin etik standartlara sahip olduklarını ifade eder ancak çok az insan bunlara uyar" ifadesi olduğu görülmektedir. Bunu "bir çıkarı olduğunda insanların çoğu yalan söyler" ifadesi takip etmektedir. En düşük ortalama ise "insanların çoğu içten içe, başkalarına yardım etmek için elinden geleni yapmaktan hoşlanmaz" ifadesine aittir. 
Sinizm düzeyleri ortalamalar ile ortaya konulmuş olup, bilişsel boyut $(\bar{x}=3,65)$ davranışsal boyut $(\bar{x}=3.02)$ ve duyuşsal boyut $(\bar{x}=3,51)$ olduğu görülmüştür. Buna göre bilişsel ve duyuşsal boyutun yüksek olduğu ve davranışsal boyutun ise orta düzeyde olduğu söylenebilir.

\section{KATILIMCILARIN ÖRGÜTSEL SINIZM DÜZEYi}

Katılımcılara sunulan ölçek maddeleri ve elde edilen verilerin ortalamaları ile standart sapma düzeyleri Tablo 4 de gösterilmiştir.

Tablo 4: Örgütsel Sinizm Eğilimine Yönelik Ortalama ve Standart Sapma Değerleri

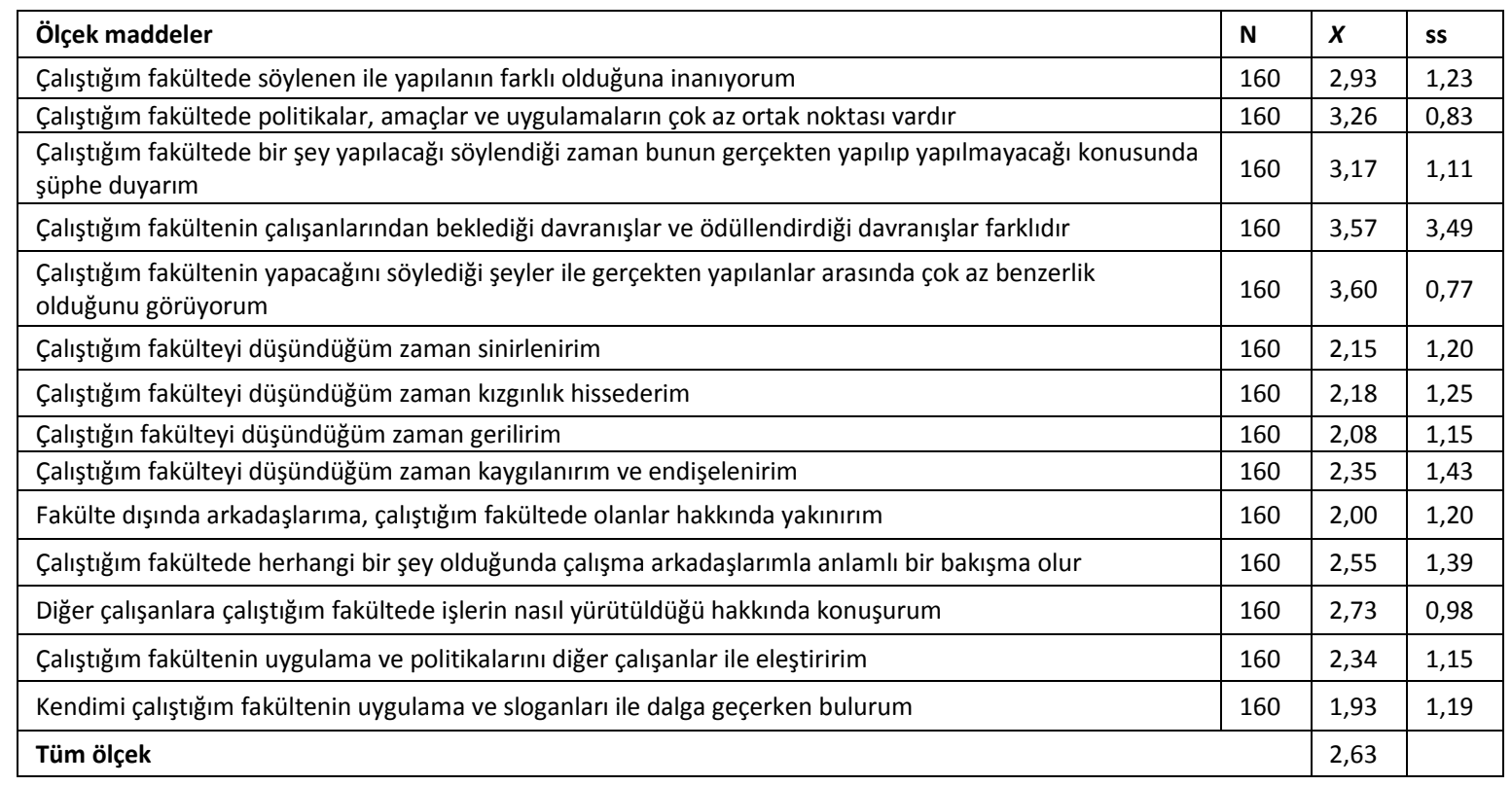

Tablo 4 incelendiğinde çalışmamıza katılanların örgütsel sinizm düzeylerinin $(\bar{x}=2,63)$ ile orta seviyede olduğu görülmektedir. Maddeler içerisinde "Çalıştığım fakültenin yapacağını söylediği şeyler ile gerçekten yapılanlar arasında çok az benzerlik olduğunu görüyorum" en yüksek ortalamaya sahip ifadedir. Bunu "Çalıştığım fakültenin çalışanlarından beklediği davranışlar ve ödüllendirdiği davranışlar farklıdır" ifadesi takip etmektedir. Çalışanların kurumlarının yapı ve işleyişinden kaynaklı sorunların olduğunu düşündükleri söylenebilir. Örgütsel sinizmin alt boyutları olan davranışsal boyutun $(\bar{x}=2,40)$, duyuşsal boyut $(\bar{x}=2,13)$, bilişsel boyutun $(\bar{x}=3,30)$ olduğu görülmektedir. Örgütsel sinizmin alt boyutlarından davranışsal ve duyuşsal sinizmin düşük olduğu buna karşın bilişsel boyutun orta düzeyde olduğu görülmektedir.

\section{SONUÇ}

Sinizm kavramı özetle diğer insanlara inanmama, güvenmeme, ortak değerleri benimsememe olarak tanımlanırken, örgütsel sinizm kavramını, örgüt mensuplarının örgüte karşı besledikleri negatif tutum olarak tanımlamak mümkündür. Örgütsel sinizmin örgüt çıkarları ve örgütün devamlılığı ile ilgili sonuçları literatürde çeşitli şekillerde belirlenmişse de, yapılan bu çalışmanın akademik eğitim kurumları ile ilgili yapılacak çalışmalar açısından yararlı olacağı düşünülmektedir. Bu çalışma Kafkas Üniversitesi akademisyenlerinin genel ve örgütsel sinizm seviyelerini ölçmek maksadı ile yapılmış, araştırma sonucunda katılımcıların genel sinizm ve örgütsel sinizm seviyelerinin orta düzeyde olduğu gözlemlenmiştir.

Örgütsel sinizmin alt boyutlarından elde edilen bulgulara davranışsal ve duyuşsal sinizmin düşük olduğu buna karşın bilişsel boyutun orta düzeyde olduğu tespit edilmiştir. Bu bulgulara göre çalışanlar, kurumlarının kendilerinin bazı beklentilerini karşılamadığını düşündüklerini buna karşın kurumlarına karşı olumsuz tutum ve davranış sergilemediklerini söylemek mümkündür. Örgütsel sinizmin alt boyutları bakımından cinsiyetler arasında farklılıkların olduğu görülmüştür. Buna göre erkek katılımcıların duyuşsal ve davranışsal sinizm algıları kadınlara göre daha yüksek olduğu belirlenmiştir. Unvanlar arasında farklııkların olup olmadığını belirlemek üzere gerçekleştirilen analizler neticesinde duyuşsal sinizm algılarında araştırma görevlileri ile okutmanlar arasında farklılıkların olduğu görülmüştür. Davranışsal alt boyutta yardımcı doçentler ile araştırma görevleri arasında ve araştırma görevlileri ile okutmanlar arasında istatistiksel olarak anlamlı farklılıklar tespit edilmiştir. Farklı iş yükünün böyle bir farklılığın ortaya çıkmasında etkili olduğu düşünülmektedir. Araştırma sadece bir üniversitenin akademik personelinden alınan verilerle sınırlıdır. Araştırma kapsamının sınırlı olması sebebiyle araştırma 
neticesinde elde edilen sonuçları genellemek mümkün değildir. Daha genelleştirilebilir sonuçlar elde etmek daha geniş örneklem üzerinde araştırmaları gerekli kılmaktadır. Bu çalışma sinizm ve örgütsel sinizm düzeyini belirlemek amacıyla gerçekleştirilmiştir. Gelecekte örgütsel sinizmi ortaya çıkaran nedenlerin ortaya çıkarılmasına yönelik çalışmalar yapılabilir.

\section{KAYNAKLAR}

ABRAHAM, R. (2000). “Organizational Cynicism: Bases and Consequences”, Eneric, Social And General Psychology Monographs, Vol; 126(3), 269-292.

ANDERSON, L.M. (1996). Employee cynicism: An examination using a Contract violation

framework. Human Relations, 49 (11), 1395-1418. ss.

ARSLAN, B. S., ŞAHIN, S., DEĞER, B. D. "Psikolojik Sözleşmenin Büro Çalışanlarının Sinik Davranışlarına Etkisi”. Süleyman Demirel Üniversitesi: 11.Ulusal Büro Yönetimi ve Sekreterlik Kongresi, 2012.

BATEMAN, T.S., SAKANO, T., FUJITA, M.(1992). "Roger, me, and my attitude: Film propaganda and cynicism toward corporate leadership". Journal of Applied Psychology, 11 (5), 768-77l.ss.

BYRNE, Z. S. and HOCHWARTER, Wayne. A. (2007). "Perceived Organizational Support and Performance Relationships Across Levels of Organizational Cynicism", Journal of Managerial Psychology, Vol; 23(1), 54-72.

CANDAN, H. “Örgütsel Sinizm ve İşgören Performansına Olası Etkileri”. Kahramanmaraş Sütçü İmam Üniversitesi iỉBF Dergisi. Sayı 1, (2013): 181-194.

ÇEKMECELIOĞLU, H; (2006), “İş Tatmini ve Örgütsel Bağlılık Tutumlarının İşten Ayrılma Niyeti ve Verimlilik Üzerindeki Etkilerinin Değerlendirilmesi: Bir Araştırma”, İş, Güç - Endüstri İlişkileri ve İnsan Kaynakları Dergisi, Haziran, 8(2), ss. 153-168.

DEAN, J.W., BRANDES P., DHARWADKAR, R. (1998). Organizational cynicism. Academy of Management Review, 23(2), 341-352. ss.

DERIN, N. “işletmelerde Geride Kalan Sendromu ve Örgütsel Güven.”, Ankara: Nobel Yayıncılık, 2011.

DELKEN, M. (2004). Organizational cynicism: A study among call centers. Unpublished master thesis, University of Maastricht.

JAMES, S. M. (2005). "Antecedents and Consequences of Cynicism in Organizations: An Examination of Potantial Positive and Negative Effects on School Systems". Doktora Tezi. College of Business The Florida State University.

KALAĞAN G. ve GÜZELLER, C. O. (2010). “Öğretmenlerin Örgütsel Sinizm Düzeylerinin İncelenmesi”. Pamukkale Üniversitesi Eğitim Fakültesi Dergisi. (27), 83-97.

KUTANiS, R. Ö. ve E. ÇETINEL, (2010), “Adaletsizlik Algısı Sinisizmi Tetikler mi?”, Kütahya Dumlupınar Üniversitesi SBE. Dergisi, Cilt: 12 (2), s. 186-195.

JAMES, M. S. L., (2005), “Antecedents and Consequences of Cynicism in Organizations: An Examination of the Potential Positive and Negative effects on school Systems". Doktora tezi. College Of Business The Florida State University.

MCCLOUGH, A.C., ROGElBERG, S.G., FISHER, G.G., BACHIOCHI, P.D. (Summer 1998). "Cynicism and the quality of an individual's contribution to an organizational diagnostic survey". Organization Development Journal, 16 (2), 31-42. ss.

ÖNCER, A.Z. (2009). "An overview of organizational cynicism and a cure suggestion: Teamwork". 2009 EABR \& TLC Conference Proceedings, Prague, Czech Republic.

ÖZDAMAR, K. (2002). Paket Programlar İle İstatistiksel Veri Analizi 1, Eskişehir: Kaan Kitabevi.

ÖZGENER, Ş., ÖĞÜT, A., KAPLAN, M. (2008). “İşgören-işveren ilişkilerinde yeni bir paradigma: Örgütsel sinizm”. M. ÖZDEVECioĞLU, H. KARADAL (ed.), Örgütsel davranışta seçme konular organizasyonların karanlık yönleri ve verimlilik azaltıcı davranışlar içinde. Ankara, ilke Yayınevi.

PARKER, S.K., A. JOHNSON, C. COLLINS ve H. NGUYEN (2013), "Making The Most of Structural Support: Moderating Influence of Employees' Clarity And Negative Affect", Academy of Management Journal, 56 (3), 867-892.

PORTER L.W., R.M. STEERS, R.T. MOWDAY ve P. V. BOULIAN (1979), “Organizational Commitment, Job Satisfaction and Turnover Among Psychiatric Technicians", Journal of Applied Psychology, 59 (5), 603-609

TURAN, Ş. "Küreselleşme Sürecinde Örgütsel Değişimi Etkileyen Bir Unsur Olarak Örgütsel Sinizm ve Karaman ili Kamu Kurumlarında Bir Çalışma”, Karamanoğlu Mehmetbey Üniversitesi Sosyal Bilimler Enstitüsü, Yüksek Lisans Tezi, Karaman: 2011. 